\title{
Prevalence of Spot Blotch (Bipolaris sorokiniana) of Wheat and its Management through Host Resistance
}

\author{
S.K. Singh ${ }^{1}$, Manmohan Singh ${ }^{1}$, V.K. $\operatorname{Razdan}^{1}$, V.B. $\operatorname{Singh}^{3}$, A.K. Singh ${ }^{1}$, \\ Sachin Gupta ${ }^{1}$, Ranbir Singh ${ }^{1}$, Anil Gupta ${ }^{1}$, Uma Shankar ${ }^{2}$, A.K. Singh ${ }^{2}$, \\ M.K. Pandey ${ }^{1}$ and Richa Sharma ${ }^{1}$ \\ ${ }^{1}$ Division of Plant Pathology, SKUAST of Jammu-180009, India \\ ${ }^{2}$ Division of Entomology, SKUAST of Jammu-180009, India \\ ${ }^{3}$ RRSS, Raya, SKUAST of Jammu-181143, India \\ *Corresponding author
}

\section{Keywords}

Spot blotch

(Bipolaris

sorokiniana),

Wheat

Article Info

Accepted:

07 January 2018

Available Online:

10 February 2018

\section{A B S T R A C T}

Survey was conducted at dough stage to assess the spot blotch disease of wheat in different locations of Jammu sub-tropics during 2015 cropping seasons. The disease was reported in all the wheat growing areas of Jammu subtropics with the maximum AIDX observed in Kathua district with the range of 29.55-48.15 per cent, followed by Samba ranging from 29.28-45.82 per cent. However, minimum disease was observed in Jammu district (30.06-40.61\%). Out of sixty two wheat genotypes evaluated against spot blotch under natural epiphytotic conditions, 8 (HD-2967, HD-3043, HP-1102, HS-277, JAUW-598, PBW-660, PBW-692 and VL-907) were observed as resistant having disease severity of 34.26 to 35.0 per cent and AUDPC value of 330.90-402.80. While as, 24 genotypes were observed as moderately resistant having disease severity of 39.45 to 57.0 per cent and AUDPC value of 429.60-742.10. The rest of wheat genotypes belong to moderately susceptible and susceptible groups and having high disease severity and AUDPC value.

\section{Introduction}

Spot blotch, caused by Bipolaris sorokiniana (Sacc.) Shoemaker is a major disease of wheat (Triticum aestivum L.), in all the six agroclimatic zones of India. During past two decades, substantial economic loss in wheat production has occurred due to the severity of spot blotch, adversely affecting the livelihood of millions of small scale farmers (Krishnendu et al., 2011). The losses in grain yield are estimated from 6.3 to $50 \%$ (Chenulu et al., 1972 and Singh et al., 2002), depending on cultivars grown. The disease also causes serious damage in seed quality and market value of the produce (Singh and Kumar, 2008). Although chemical control of the disease has been worked out (Singh et al., 2014), yet deployment of resistant cultivars remains a top priority. The status of the 
disease varied year to year and season to season. Therefore, an extensive survey were conducted in different wheat growing areas of Jammu subtropics to know the present status of spot blotch disease. Moreover, screening of popular varieties and elite germplasm of wheat was also evaluated against spot blotch under natural epiphytotic conditions, to identify the sources of resistance against the disease in order to manage it and also to use the resistant germplasm in breeding for resistance.

\section{Materials and Methods}

\section{Status of spot blotch disease in Jammu subtropics}

Survey was conducted to record the severity of spot blotch in wheat fields located in subtropical zones of Jammu Division comprising of Jammu, Samba and Kathua districts, during of Jammu the month of March, 2015. Five fields at each location were selected randomly in each district and data were collected at weekly intervals by random sampling method. Disease intensity/average infection index (AIDX) was calculated on the bases of 0-4 scale proposed by Chenulu and Singh (1964).

$$
\text { AIDX }=\frac{\text { Class rating } \times \text { Class frequency }}{\text { Total number of leaves } \mathrm{x} \text { Maximum Class frequency }}
$$

The scale used for calculating Average Infection Index (AIDX) was as follows:

$0=$ no infection

$1=1-25$ per cent leaf area infected

$2=26-50$ per cent leaf area infected

$3=51-75$ per cent leaf area infected

$4=>75$ per cent leaf area infected

Sixty two wheat genotypes viz. Agra Local, AKW-1071, DBW-14, DBW-39, DBW-88, DBW-90, DL-784-3, DPW-621-50, Durgapur65, G-W-40, HD-2733, HD-2851, HD-2888,
HD-2967, HD-2985, HD-3043, HD-3059, HD-3086, HI-1563, HP-1102, HS-1138, HS207, HS-277, HS-375, HS-490, HS-507, HS542, JAUW-584, JAUW-595, JAUW-598, K0307, K-1006, K-8027, Kharchia 65, MP3382, Narmada -112, PBW-175, PBW-343, PBW-550, PBW-590, PBW-644, PBW-660, PBW-692, PDW-233, PDW-291, PDW-314, RAJ-3077, RAJ-3765, RAJ-4015, RAJ-4037, RAJ-4083, RSP-561, Sarbati Sonara, Sonalika, VL-804, VL-829, VL-892, VL-907, WH-1021, WH-1080, WH-1105 and WH1124 , procured from different sources were screened for spot blotch under natural epiphytotic conditions during 2014-2015 Rabi seasons at University Research Farm, Chatha. The experiment was laid out in randomized block design with three replications. Each genotype was sown in $2 \mathrm{~m}$ rows spaced $22.5 \mathrm{~cm}$ apart in $4^{\text {th }}$ week of December.

The spore suspension $B$. sorokiniana was prepared from 21-day old culture of pathogen grown on sorghum seeds. Inoculation with the test pathogen was made by spraying spore suspension $\left(4.3 \times 10^{4}\right.$ spores $/ \mathrm{ml}$ of water) on wheat genotypes including spreader rows at tillering stage and subsequent two sprays were made to create artificial epiphytotic conditions in the field to screen wheat varieties. The field was irrigated after inoculation to maintain proper humidity. Disease observations were started when the first lesion appeared (March $21^{\text {st }}$ ) on the lower leaves and repeated at 10day intervals till the leaves were green. The observations on per cent blighted area as per 0-9 scale (Saari and Prescott, 1975) were recorded. The terminal disease severity, used to classify the wheat genotypes into different groups as reported by Singh et al., (2015). The categorization of genotypes for resistance to spot blotch was done as, HR: average disease score range 00-13, R: average score 14-35, MR: average score 36-57, MS: average score 58-69 and S: average score $>69$. 


\section{Results and Discussion}

A perusal of the data (Table 1) revealed that the disease occurred in all the fifteen locations surveyed and AIDX varied from 29.28 to 48.15 per cent during 2014-15 crop season. The maximum AIDX (48.15\%) was recorded at Barnoti in district Kathua, whereas minimum AIDX (29.28\%) was recorded at Rajpura in district Samba. In Jammu district, the AIDX ranged from 30.06 to 40.61 per cent with mean intensity of $33.89 \pm 1.63$ per cent. The maximum AIDX was recorded at Akalpur (40.61\%) followed by R. S. Pura $(35.40 \%)$ and the lowest in Marh (30.06\%). In Samba district, the AIDX ranged from 29.28 to 45.82 per cent with mean intensity of $33.99 \pm 1.68$ per cent. The maximum AIDX was recorded at Sapwal (45.82\%) followed by Ghagwal (34.09\%) and the lowest in Rajpura (29.28\%). In Kathua district, the AIDX ranged from 29.55 to 48.15 per cent with mean intensity of $35.25 \pm 1.26$ per cent. The maximum AIDX was observed at Barnoti (48.15\%) followed by Rajbag (35.80\%) and the lowest in Hiranagar $(29.55 \%)$.

The predominance of spot blotch of wheat has been reported from Bihar, Delhi, Gujarat, Haryana, Himachal Pradesh, Jammu \& Kashmir, Karnataka, Kerala, Madhya Pradesh, Maharashtra, Orissa, Punjab, Rajasthan, Tamilnadu, Uttar Pradesh and West Bengal states of India (Singh et al., 2001). Krishnendu et al., (2011) observed that great yield losses occurred by the disease, when flag leaf and the leaf below the flag leaf were infected before the emergence of ear head. Our findings are in complete agreement with Mahto et al., (2002) and Singh et al., (2004) who also reported similar findings. Joshi et al., (2002) also observed that spot blotch or foliar blight was most concerning disease in warm and humid regions of India and other South Asian countries due to its wide spread prevalence and increasing severity.
Screening of 62 wheat genotypes under field conditions against spot blotch disease on 0-9 scale showed that the infection varied from 5.10 to 29.12 per cent and all the genotypes were infected on $20^{\text {th }}$ March, 2015 (Table 2), whereas, 13.41 to 59.62 per cent infection was recorded on $30^{\text {th }}$ of March, 2015. At the end of the crop season the terminal disease severity of different genotypes was highest and varied from 34.26 to 90.00 per cent. The Area Under Disease Progress Curve (AUDPC) varied from 330.90 to 1191.80 , showing the fast progress of disease in all genotypes. It was observed that different wheat genotypes expressed varied type of disease response against $B$. sorokiniana under artificial epiphytotic conditions in the field.

A perusal of data (Table 3) revealed that no wheat genotype under the study appeared to be the highly resistant to the $B$. sorokiniana (spot blotch disease). However, under natural epiphytotic conditions, wheat germplasm, HD2967, HD-3043, HP-1102, HS-277, JAUW598, PBW-660, PBW-692, PDW-291 and VL907 were observed as resistant, with AUDPC ranging between 330.90-402.80, and DBW88, DL-784-3, DPW-621-50, HD-2733, HD3059, HD-3086, HI-1563, HS-1138, HS-207, HS-375, HS-490, HS-507, HS-542, JAUW584, JAUW-595, Narmada-112, PDW-291, PDW-314, RAJ-4037, RSP-561, WH-1021, WH-1080, WH-1105 and WH-1124 were ranked as moderately resistant with AUDPC ranging from 429.60-742.10. Whereas, AKW1071, DBW-14, DBW-39, DBW-90, Durgapur-65, G-W-40, HD-2851, HD-2888, HD-2985, K-1006, K-8027, MP-3382, PBW175, PBW-550, PBW-590, PBW-644, PDW233, RAJ-3077, RAJ-3765, RAJ-4083, Sarbati Sonara, VL-804, VL-829 and VL-892 were graded as moderately susceptible and Agra Local, K-0307, Kharchia 65, PBW-343, RAJ4015 and Sonalika as susceptible. 
Table.1 Average Infection Index (AIDX) of spot blotch of wheat in different locations of Jammu sub-tropics

\begin{tabular}{|c|c|c|}
\hline District & Location & AIDX * \\
\hline \multirow[t]{7}{*}{ Jammu } & Marh & 30.06 \\
\hline & Bishnah & 31.03 \\
\hline & Akalpur & 40.61 \\
\hline & R.S. Pura & 35.40 \\
\hline & Kotli & 32.37 \\
\hline & $\operatorname{Mean} \pm$ SE(m) & $33.89 \pm 1.63$ \\
\hline & Range & $30.06-40.61$ \\
\hline \multirow[t]{7}{*}{ Samba } & Vijaypur & 30.56 \\
\hline & Sapwal & 45.82 \\
\hline & Ghagwal & 34.09 \\
\hline & Rajpura & 29.28 \\
\hline & Jatwal & 30.22 \\
\hline & Mean \pm SE $(m)$ & $33.99 \pm 1.68$ \\
\hline & Range & 29.28-45.82 \\
\hline \multirow[t]{7}{*}{ Kathua } & Hiranagar & 29.55 \\
\hline & Chadwal & 31.67 \\
\hline & Rajbag & 35.80 \\
\hline & Barnoti & 48.15 \\
\hline & Laget Moh & 31.11 \\
\hline & Mean \pm SE $(m)$ & $35.25 \pm 1.26$ \\
\hline & Range & $29.55-48.15$ \\
\hline
\end{tabular}

*AIDX = Average infection index 
Table.2 Evaluation of wheat genotypes against spot blotch disease caused by Bipolaris sorokiniana

\begin{tabular}{|c|c|c|c|c|c|c|}
\hline \multirow[t]{2}{*}{ S.No } & \multirow[t]{2}{*}{ Genotype } & \multicolumn{3}{|c|}{ Per cent disease severity } & \multirow{2}{*}{$\begin{array}{l}\text { Disease } \\
\text { reaction }\end{array}$} & \multirow[t]{2}{*}{ *AUDPC } \\
\hline & & $20^{\text {th }}$ March & 30 $^{\text {th }}$ March & $9^{\text {th }}$ April & & \\
\hline 1 & Agra Local & 22.50 & 56.21 & 84.12 & $\mathrm{~S}$ & 1095.2 \\
\hline 2 & AKW-1071 & 12.33 & 34.12 & 68.10 & MS & 743.30 \\
\hline 3 & DBW-14 & 12.20 & 35.60 & 58.20 & MS & 708.00 \\
\hline 4 & DBW-39 & 13.21 & 35.42 & 65.23 & MS & 746.40 \\
\hline 5 & DBW-88 & 12.30 & 34.00 & 55.41 & MR & 678.50 \\
\hline 6 & DBW-90 & 12.60 & 36.21 & 66.21 & MS & 756.15 \\
\hline 7 & DL-784-3 & 13.35 & 34.56 & 56.30 & MR & 693.80 \\
\hline 8 & DPW-621-50 & 13.00 & 24.45 & 45.50 & MR & 537.00 \\
\hline 9 & Durgapur-65 & 12.50 & 35.12 & 58.41 & MS & 705.70 \\
\hline 10 & G-W-40 & 22.10 & 36.10 & 58.16 & MS & 762.30 \\
\hline 11 & HD-2733 & 13.11 & 35.41 & 54.67 & MR & 693.00 \\
\hline 12 & HD-2851 & 22.21 & 35.45 & 59.61 & MS & 763.60 \\
\hline 13 & HD-2888 & 13.52 & 36.41 & 64.70 & MS & 752.70 \\
\hline 14 & HD-2967 & 5.10 & 13.41 & 34.26 & $\mathrm{R}$ & 330.90 \\
\hline 15 & HD-2985 & 12.48 & 36.45 & 66.21 & MS & 757.90 \\
\hline 16 & HD-3043 & 4.56 & 15.26 & 35.00 & $\mathrm{R}$ & 350.40 \\
\hline 17 & HD-3059 & 12.42 & 25.45 & 48.21 & MR & 557.60 \\
\hline 18 & HD-3086 & 12.00 & 35.21 & 44.52 & MR & 634.70 \\
\hline 19 & HI-1563 & 18.52 & 34.53 & 48.12 & MR & 678.50 \\
\hline 20 & HP-1102 & 6.20 & 14.23 & 34.85 & $\mathrm{R}$ & 347.50 \\
\hline 21 & HS-1138 & 12.86 & 26.16 & 46.53 & MR & 558.50 \\
\hline 22 & HS-207 & 18.52 & 36.45 & 57.00 & MR & 742.10 \\
\hline 23 & HS-277 & 4.50 & 16.24 & 34.82 & $\mathrm{R}$ & 359.00 \\
\hline 24 & HS-375 & 12.62 & 25.45 & 46.52 & MR & 550.20 \\
\hline 25 & HS-490 & 12.58 & 25.00 & 47.23 & MR & 549.00 \\
\hline 26 & HS-507 & 13.25 & 25.45 & 46.25 & MR & 552.00 \\
\hline 27 & HS-542 & 12.25 & 24.15 & 46.52 & MR & 535.30 \\
\hline 28 & JAUW-584 & 12.14 & 23.46 & 45.85 & MR & 524.50 \\
\hline 29 & JAUW-595 & 12.45 & 24.47 & 56.00 & MR & 586.90 \\
\hline 30 & JAUW-598 & 8.14 & 16.25 & 35.00 & $\mathrm{R}$ & 378.20 \\
\hline
\end{tabular}




\begin{tabular}{|l|l|c|c|c|c|c|}
\hline $\mathbf{3 1}$ & K-0307 & 23.12 & 46.25 & 78.12 & S & 968.70 \\
\hline $\mathbf{3 2}$ & K-1006 & 22.45 & 34.26 & 68.45 & MS & 797.10 \\
\hline $\mathbf{3 3}$ & K-8027 & 21.36 & 34.25 & 67.15 & MS & 785.00 \\
\hline $\mathbf{3 4}$ & Kharchia 65 & 23.15 & 46.52 & 78.21 & S & 972.00 \\
\hline $\mathbf{3 5}$ & MP-3382 & 19.51 & 35.26 & 67.45 & MS & 787.40 \\
\hline $\mathbf{3 6}$ & Narmada -112 & 13.26 & 24.86 & 46.79 & MR & 548.80 \\
\hline $\mathbf{3 7}$ & PBW-175 & 23.25 & 42.21 & 60.52 & MS & 840.90 \\
\hline $\mathbf{3 8}$ & PBW-343 & 19.12 & 45.23 & 83.50 & S & 965.50 \\
\hline $\mathbf{3 9}$ & PBW-550 & 23.52 & 36.41 & 58.75 & MS & 775.40 \\
\hline $\mathbf{4 0}$ & PBW-590 & 17.45 & 35.42 & 67.23 & MS & 777.60 \\
\hline $\mathbf{4 1}$ & PBW-644 & 24.00 & 45.26 & 77.90 & MS & 962.10 \\
\hline $\mathbf{4 2}$ & PBW-660 & 5.30 & 15.41 & 34.62 & R & 353.70 \\
\hline $\mathbf{4 3}$ & PBW-692 & 8.52 & 18.52 & 35.00 & R & 402.80 \\
\hline $\mathbf{4 4}$ & PDW-233 & 14.52 & 36.51 & 68.45 & MS & 779.90 \\
\hline $\mathbf{4 5}$ & PDW-291 & 10.00 & 18.24 & 39.45 & MR & 429.60 \\
\hline $\mathbf{4 6}$ & PDW-314 & 11.36 & 20.45 & 40.35 & MR & 463.00 \\
\hline $\mathbf{4 7}$ & RAJ-3077 & 23.10 & 46.53 & 68.45 & MS & 923.00 \\
\hline $\mathbf{4 8}$ & RAJ-3765 & 25.21 & 45.12 & 67.15 & MS & 913.00 \\
\hline $\mathbf{4 9}$ & RAJ-4015 & 27.26 & 56.12 & 84.24 & S & 1118.70 \\
\hline $\mathbf{5 0}$ & RAJ-4037 & 11.23 & 25.12 & 50.13 & MR & 558.00 \\
\hline $\mathbf{5 1}$ & RAJ-4083 & 15.23 & 36.45 & 62.30 & MS & 752.15 \\
\hline $\mathbf{5 2}$ & RSP-561 & 13.52 & 29.53 & 50.14 & MR & 613.60 \\
\hline $\mathbf{5 3}$ & Sarbati Sonara & 23.52 & 38.12 & 68.16 & MS & 839.60 \\
\hline $\mathbf{5 4}$ & Sonalika & 29.12 & 59.62 & 90.00 & S & 1191.80 \\
\hline $\mathbf{5 5}$ & VL-804 & 16.23 & 38.15 & 60.23 & MS & 763.80 \\
\hline $\mathbf{5 6}$ & VL-829 & 20.42 & 38.42 & 63.42 & MS & 803.40 \\
\hline $\mathbf{5 7}$ & VL-892 & 13.26 & 36.12 & 58.12 & MS & 718.10 \\
\hline $\mathbf{5 8}$ & VL-907 & 6.20 & 17.26 & 35.00 & R & 378.60 \\
\hline $\mathbf{5 9}$ & WH-1021 & 12.41 & 34.36 & 47.52 & MR & 643.20 \\
\hline $\mathbf{6 0}$ & WH-1080 & 13.25 & 25.41 & 45.32 & MR & 546.90 \\
\hline $\mathbf{6 1}$ & WH-1105 & 12.42 & 35.46 & 47.95 & MR & 656.40 \\
\hline $\mathbf{6 2}$ & WH-1124 & 13.25 & 33.25 & 49.52 & MR & 646.30 \\
\hline
\end{tabular}


Table.3 Reaction of different wheat genotypes against spot blotch (B. sorokiniana) disease of wheat

\begin{tabular}{|l|c|c|l|}
\hline Disease reaction & Category & *AUDPC value & \multicolumn{1}{|c|}{ Wheat genotype } \\
\hline Highly resistance (HR) & $00-13$ & - & \multicolumn{1}{c|}{ Nil } \\
\hline Resistant (R) & $14-35$ & $330.90-402.80$ & $\begin{array}{l}\text { HD-2967, HD-3043, HP-1102, HS-277, JAUW-598, PBW-660, } \\
\text { PBW-692, VL-907 }\end{array}$ \\
\hline Moderately resistant (MR) & $36-57$ & $429.60-742.10$ & $\begin{array}{l}\text { DBW-88, DL-784-3, DPW-621-50, HD-2733, HD-3059, HD- } \\
3086, \text { HI-1563, HS-1138, HS-207, HS-375, HS-490, HS- 507, HS- } \\
542, \text { JAUW-584, JAUW-595, Narmada-112, PDW-291, PDW- } \\
314, \text { RAJ-4037, RSP-561, WH-1021, WH-1080, WH-1105, WH- } \\
1124\end{array}$ \\
\hline $\begin{array}{l}\text { Moderately susceptible } \\
\text { (MS) }\end{array}$ & $58-78$ & $746.40-962.10$ & $\begin{array}{l}\text { AKW-1071, DBW-14, DBW-39, DBW-90, Durgapur-65, G-W- } \\
40, \text { HD-2851, HD-2888, HD-2985, K-1006, K-8027, MP-3382, } \\
\text { PBW-175, PBW-550, PBW-590, PBW-644, PDW-233, RAJ- } \\
3077, \text { RAJ-3765, RAJ-4083, Sarbati Sonara, VL-804, VL-829, VL- } \\
892 .\end{array}$ \\
\hline $\begin{array}{l}\text { Susceptible (S) } \\
\text { *Area Under Disease Progress Curve (AUDPC) }\end{array}$ & $\begin{array}{l}\text { Agra Local, K-0307, Kharchia 65, PBW-343, RAJ-4015, } \\
\text { Sonalika. }\end{array}$ \\
\hline
\end{tabular}


The present result was found to be in conformation with findings of Khan and Chowdhury (2011) who evaluated 422 spring wheat germplasm from India, CIMMYT and China against $B$. sorokiniana, under natural epiphytotic conditions and reported 52 as resistant, 180 as moderately susceptible, 171 as susceptible and rest as highly susceptible. Ibeagha et al., (2005) reported higher levels of resistance in Yangmai 6, M 3 (W7976), Shanghai 4 and Chiriya 7 when compared with Sonalika. Chaurasia et al., (1999) and Dubin et al., (1998) reported low to moderate levels of resistance to spot blotch in international wheat germplasm.

Sources of resistance against $B$. sorokiniana were also identified by Aggarwal (2011) under natural and artificial epiphytotic conditions. Our results are in accordance with the findings of Singh et al., (2005), who reported that wheat genotypes namely, $\mathrm{CB}$ (BW)-351, CB (BW)-355, MRANG ALD/AN'S' MON's'/ALD's', UHU, BAU 4, K 9204, BW 14989, HW 2012 and HW 2014 were resistant to spot blotch (B. sorokiniana). Mexican varieties Alovdra, Cocoraine, Cugap; Chinese genotypes, Ning 8201, Longmai 10, Yangmai 6 and Brazilian cultivars, BH 1146, CNT 2, PAT 7219, Ocepar 7 have been noted as best resistance (Mehta, 1985; Singh et al., 2007). The genotypes identified as resistant may be useful in breeding programme against spot blotch disease and also useful for deployed in the areas getting high disease pressure over years to contain losses in yield.

\section{References}

Aggarwal, R. 2011. Progress and challenges towards reducing spot blotch disease of wheat. Indian Phytopathology, 64: 322328.

Chaurasia, S., Joshi, A. K., Dhari, R., Chand, R. 1999. Resistance to foliar blight of wheat: a search. Genetic Resources and Crop Evolution, 46: 469-475.

Chenulu, V. V. and Singh, A. 1964. A note on estimation of losses due to leaf blight of wheat caused by Alternaria triticina. Indian Phytopathology, 17: 254-256.

Chenulu, V. V., Singh, Amar and Joshi, L. M. 1970. Estimation of losses caused by leaf blight of wheat caused by Alternaria triticina. In: Plant Disease Problems. Raychaudhuri, S. P. et al., (Eds.). IPS, IARI, New Delhi, pp. 28-31.

Dubin, H. J., Arun, B., Begum, S. N., Bhatta, M. R., Dhari, R., Goel, L. B., Joshi, A. K., Khanna, B. M., Malaker, P. K., Pokhrel, D. R., Rahman, M. M., Saha, N. K., Shaheed, M. A., Sharma, R. C., Singh, A. K., Singh, R. M., Singh, R. V., Vargas, M. and Verma, P. C. 1998. Results of the South Asia regional Helminthosporium leaf blight and yield experiments, 1993-1994. In: Helminthosporium blights of wheat: Spot blotch and tan spot (Eds. Duveiller, E., Dubin, H. J., Reeves, J., Mc Nab, A.), CIMMYT, Mexico, pp. 182-187.

Ibeagha, A. E., Huckelhoven, R., Schafer, P., Singh, D. P. and Kogel, K. H. 2005. Model wheat genotypes as tool to uncover effective defence mechanism against the hemobiotophic fungus Bipolaris sorokiniana. Phytopathology, 95: 528-532.

Joshi, A. K., Chand, R. and Arun, B. 2002. Relationship of plant height and days to maturity with resistance to spot blotch in wheat. Euphytica, 123: 221-228.

Khan, H. and Chowdhury, S. 2011. Identification of resistance source in wheat germplasm against spot blotch disease caused by Bipolaris sorokiniana. Archives of Phytopathology and Plant Protection, 44: 840-844.

Krishnendu, A., Dutta, A. K. and Pradhan, P. 2011. Bipolaris sorokiniana (Sacc.) Shoem: The most destructive wheat fungal pathogen in the warmer areas. Australian Journal of Crop Sciences, 5: 1064-1071. 
Mahto, B. N., Singh, D. V., Srivastava, K. D. and Aggarwal, R. 2002. Mycoflora associated with leaf blight of wheat and pathogenic behaviour of spot blotch pathogen. Indian Phytopathology, 53: 319322.

Mehta, Y. R. 1985. Breeding wheats for resistance to spot blotch. In: Proceedings of the International Symposium on Wheats for More Tropical Environments (Eds. Villareal, R. L. and Klatt, A. R.), pp. 135144, CIMMYT, Mexico, pp. 354.

Saari, E. E. and Prescott, J. M.1975. A scale for appraising the foliar intensity of wheat diseases. Plant Disease Reporter, 59: 377380.

Singh, D. P. and Kumar, P. 2008. Role of spot blotch (Bipolaris sorokiniana) in deteriorating seed quality, its management in different wheat genotypes using fungicidal seed treatment. Indian Phytopathology, 61: 49-54.

Singh, D. P., Sharma, A. K., Amerika Singh, Singh, R. V., Tewari, A. N., Singh, A. K., Singh, R. N., Singh, S. P., Khanna, B. M., Dodan, D. S., Bagga, P. S. and Kalappanavar, I. K. 2002. Losses caused due to leaf blight in wheat in different agroclimatic zones of India. Plant Disease Research, 17: 313-317.

Singh, D. P., Sharma, Indu., Singh, Ishwar., Jindal, M. M., Mann, S. K., Chowdhury, A. K., Mahapatra, S. Singh, K. P., Kumar, J., Deepshikha, Srivastava, K., Vaish, S. S., Chand, R.., Dodan, D. S., Singh, S. P., Verma, J., DAS, S. Y., Karwasra, S. S.,
Pradhan, A. C., Mukhopadhyay, S. K., Dutta, S., Kalappanavar, I. K., Solanki, I. S., Kumar, A., Azad, C. S. and Lal, H. C. 2015. Evaluation of sources of resistance to leaf blight (Bipolaris sorokiniana and Alternaria triticina) in wheat (Triticum aestivum) and Triticale. Indian Phytopathology, 68: 221-222.

Singh, D. P., Singh, Atul, Solanki, I. S., Singh, S. P., Verma, J., Mahapatra, Sunita, Mukhopadhyay, S. K. and Dutta, S. 2014. Management of spot blotch of wheat caused by Bipolaris sorokiniana in wheat using fungicides. Indian Phytopathology, 67: 308-310.

Singh, G., Singh, D. P., Chatrath, R., Singh, B. S., Singh, G. P., Singh, S. K. and Shoran, J. 2007. Combating leaf blight in wheat through resistance breeding. Indian Journal of Genetics, 67: 293-296.

Singh, K. P., Tewari, A. N., Srivastava, K. and Singh, T. 2005. Assessment of loss due to leaf blight (Bipolaris sorokiniana and Alternaria tritici) of wheat (Triticum aestivum L.) in foot-hills area of Uttaranchal. Indian Journal of Agricultural Sciences, 75: 447-448.

Singh, R. N., Singh, A. K., Singh, S. P. and Singh, B. N. 2001. Prevalence and distribution of foliar blight pathogen attacking wheat in India. Indian Phytopathology, 54: 175-178.

Singh, S. K., Srivastava, K. D. and Singh, D. V. 2004. Pathogenic behaviour of leaf blight organisms on wheat. Indian Phytopathology, 57: 319-322.

\section{How to cite this article:}

Singh, S.K., Manmohan Singh, V.K. Razdan, V.B. Singh, A.K. Singh, Sachin Gupta, Ranbir Singh, Anil Gupta, Uma Shankar, A.K. Singh, M.K. Pandey and Richa Sharma. 2018. Prevalence of Spot Blotch (Bipolaris sorokiniana) of Wheat and its Management through Host Resistance. Int.J.Curr.Microbiol.App.Sci. 7(02): 686-694. doi: https://doi.org/10.20546/ijcmas.2018.702.086 